\title{
Review
}

Journal of Innate

Immunity
J Innate Immun 2010;2:3-16

DOI: $\underline{10.1159 / 000242419}$
Received: July 13, 2009

Accepted after revision: August 18, 2009 Published online: September 24, 2009

\section{The Genetics of Ficolins}

\author{
Peter Garred $^{\mathrm{a}} \quad$ Christian Honoréa $\quad$ Ying Jie Ma $^{\mathrm{a}} \quad$ Sara Rørvig ${ }^{\mathrm{b}} \quad$ Jack Cowland ${ }^{\mathrm{b}}$ \\ Niels Borregaard ${ }^{b}$ Tina Hummelshøj ${ }^{a}$ \\ a Laboratory of Molecular Medicine, Department of Clinical Immunology, and ${ }^{\mathrm{b}}$ Granulocyte Laboratory, \\ Department of Hematology, Rigshospitalet, Faculty of Health Sciences, University of Copenhagen, \\ Copenhagen, Denmark
}

\author{
Key Words \\ Complement • Evolution - FCN1 - FCN2 - FCN3 • Ficolin • \\ Genetics $\cdot$ Lectin pathway
}

\begin{abstract}
Ficolins constitute a family of proteins whose biological role has been an enigma for many years. Over the past few years it has become evident that ficolins are part of the innate immune system and function as recognition molecules in the complement system. The 3 human ficolins, ficolin-1 (M-ficolin), ficolin-2 (L-ficolin) and ficolin-3 (H-ficolin or Hakata antigen) are encoded by the FCN1, FCN2 and FCN3 genes, respectively. Phylogenetic studies suggest that ficolins are of ancient origin. Ficolin-3 seems to be the most ancient molecule, from a phylogenetic perspective. Searches in databases and phylogenetic tree analysis demonstrate that the ficolin precursor has gone through an expansion involving independent duplication events in the different branches of the evolutionary tree. Of particular interest is the prediction that ficolin-1 appears to be present as an ortholog molecule. All human FCN genes are polymorphic. The FCN2 gene encoding ficolin-2, contains polymorphisms that affect ligand binding, while differences in the serum levels are associated with promoter polymorphisms. Recently, a frame-shift variation in the FCN3 gene was described, leading to ficolin-3 deficiency and defective complement activation. This FCN3 variation was also shown to be associated with immunode-
\end{abstract}

ficiency. This survey summarizes the current phylogenetic and inter-individual molecular understanding of the $F C N$ genes.

Copyright $\odot 2009$ S. Karger AG, Basel
Important innate immune defence mechanisms rely on evolutionary conserved pattern-recognition molecules, which provide first-line assistance in clearance of pathogens and endogenous debris. These molecules exist both as cell-associated receptors and as soluble molecules. Examples of cell-associated pattern recognition molecules are Toll-like receptors (TLRs) [1] and intracellular NOD-like receptors [2], while soluble pattern-recognition molecules are exemplified by the pentraxin family of proteins [3], the lung surfactant proteins [4] and the initiator molecules of the complement cascade [5].

The complement system can be activated through 3 pathways: the classical pathway initiated by C1q; the alternative pathway initiated by spontaneous hydrolysis of complement factor $\mathrm{C} 3$ or direct pattern recognition of properdin, and the lectin complement pathway. Mannose-binding lectin (MBL) was regarded for many years as the prototypic initiator of the lectin pathway. However, due to the pioneering work of Matsushita, Fujita and colleagues [6-8], it is now established that the ficolin family of proteins utilizes the same serine proteases (MBL-as-

\section{KARGER}

Fax +4161306 1234

E-Mail karger@karger.ch

www.karger.com (c) 2009 S. Karger AG, Basel

$1662-811 \mathrm{X} / 10 / 0021-0003 \$ 26.00 / 0$

Accessible online at:

www.karger.com/jin
Prof. Dr. Peter Garred

Laboratory of Molecular Medicine, Department of Clinical Immunology Sect. 7631, Rigshospitalet, Faculty of Health Sciences, University of Copenhagen Blegdamsvej 9, DK-2100 Copenhagen (Denmark)

Tel. +45 3545 7631, Fax +453545 8766, E-Mail garred@post5.tele.dk 
sociated serine proteases) to activate the complement system as MBL, although with varying efficiency.

Ficolins have been identified in a range of different species, such as humans [9-13], mice [14], chickens [15] hedgehogs [16], frogs [17] and ascidians [18]. In humans, 3 different ficolins have been described: ficolin-1 (M-ficolin, ficolin/P35-related protein), ficolin-2 (L-ficolin, ficolin/P35, Hucolin, EBP-37) and ficolin 3 (H-ficolin, Hakata antigen, thermolabile $\beta 2$-macroglycoprotein). In rodents and pigs only 2 ficolins, ficolin-A (or $\alpha$ ) and ficolin-B (or $\beta$ ) have been described.

Ficolin-1 was primarily regarded solely as a cellular associated molecule found on the surface of circulating monocytes and in their cytoplasm [19]. Its mRNA expression is down-regulated and eventually terminated during differentiation of monocytes into macrophages and immature dendritic cells [20-22]. However, the expression may be re-induced in mature macrophages when cells are treated with the TLR-4 ligand LPS or the TLR-2 ligand Pam3Cys [23]. Phagocytosis of Escherichia coli by cells of the pro-monocytic cell line U937 is inhibited by an antibody against recombinant ficolin-1, suggesting that surface ficolin-1 acts as a phagocytic receptor [19]. However, ficolin-1 does not contain a typical transmembrane domain and whether the protein is tethered to the monocytic membrane directly or through other molecules remains to be elucidated. The function of cytoplasmic ficolin-1 in monocytes has not been studied, but based on its binding properties, ficolin-1 could act as an intracellular recognition molecule analogous to some of the TLRs and NOD molecules [24]. Ficolin-1 is also detected in secretory granules in the cytoplasm of neutrophils and type II alveolar epithelial cells in the lung, but the function in these cells remains to be defined $[8,25]$. Recombinant ficolin-1 has been shown to activate the complement system $[8,25]$. However, the complement activation potential of ficolin-1 appears to be less than for ficolin-2 and ficolin-3 [26]. Recently, it has been demonstrated that ficolin-1 indeed is secreted into the extracellular environment from monocytes and macrophages [22].

Ficolin-2 is predominantly expressed by hepatocytes and secreted into the blood stream [27-31]. Upon binding to microorganisms, ficolin-2 acts as an opsonin and enhances phagocytosis [10]. It has been suggested that receptors for ficolins may be present on phagocytic cells [32] but such receptors have not yet been found.

Ficolin-3 was initially identified independently as the Hakata auto-antigen recognised by autoantibodies in the sera of systemic lupus erythematosus patients, and as a thermo-labile serum macro-protein [33, 34]. It appears that the presence of these auto-antibodies is associated with disease activity, low levels of ficolin-3, and hypocomplementaemia. Ficolin-3 is synthesised in the liver by hepatocytes and bile duct epithelial cells and it is secreted into both the bile duct and the circulation [35]. Ficolin-3 is also produced by ciliated bronchial epithelial cells and by type II alveolar epithelial cells in the lung and is secreted into the bronchial lumen and into the alveolar space.

\section{Ficolin Structure}

Ficolins exist as multimeric proteins consisting of 34$35 \mathrm{kDa}$ subunits [26, 36]. Human ficolin-1 and ficolin-2 are $80 \%$ homologous at the amino acid level, whereas ficolin-3 is only $48 \%$ homologous with ficolins 1 and 2 . The polypeptide chains of ficolins 1, 2 and 3 contain 326,313 and 299 amino acids, respectively. The proteins share certain structural elements, including an $\mathrm{N}$-terminal domain that contains cysteine residues, a collagen-like domain with typical Gly-Xaa-Yaa repeats of varying length, and a C-terminal carbohydrate recognition domain called the fibrinogen-like binding (FBG) domain. In contrast to other collagen-like defence molecules, such as MBL, pulmonary surfactant-associated protein (SP)-A and SP-D, the ficolins do not contain the typical $\alpha$-helical neck region between the collagen-like region and the recognition domain. Nevertheless, the overall structure of the ficolins is similar to the structure of MBL, SP-A and SP-D. They all have a collagen-like sequence, which enables the assembly of trimeric structures composed of 3 identical polypeptide chains, or 3 almost identical chains for SP-A, which coil into triplets. Based on these trimers, the molecules are further assembled into higher-order oligomers.

The ficolins are composed of 4 or more trimers linked together by disulfide bonds and are thus very similar to MBL (fig. 1). The collagen-like domain interacts with the MBL-associated serine proteases, thereby enabling activation of the complement system $[6,8,37]$. The polar arrangement of the FBG domains enables the proteins to bind negatively charged carbohydrates such as $\mathrm{N}$-acetylglucosamine (GlcNAc) and other acetylated compounds [38].

The FBG domain is similar to the C-terminal region of fibrinogen $\beta$ and $\gamma$ chains $[39,40]$, but the FBG domain is also found in tenascins [41] and in the microfibril-associated protein [42]. The horseshoe crab Tachypleus tri- 
Fig. 1. Structural organisation of MBL and ficolins. MBL and the ficolins contain a short $\mathrm{N}$-terminal cysteine-rich region followed by a collagen-like sequence, a divergent C-terminal carbohydrate binding domain called carbohydrate-recognition binding domain (CRD) for MBL and fibrinogen-like domain (FBG) for the ficolins. The polypeptides form triple helices in the collagen-like region, which further associate into higher oligemeric forms. The C-terminal enables the proteins to bind to ligands and the collagen-like domains associate with the MBL-associated serine proteases, thereby activating the lectin pathway of complement.

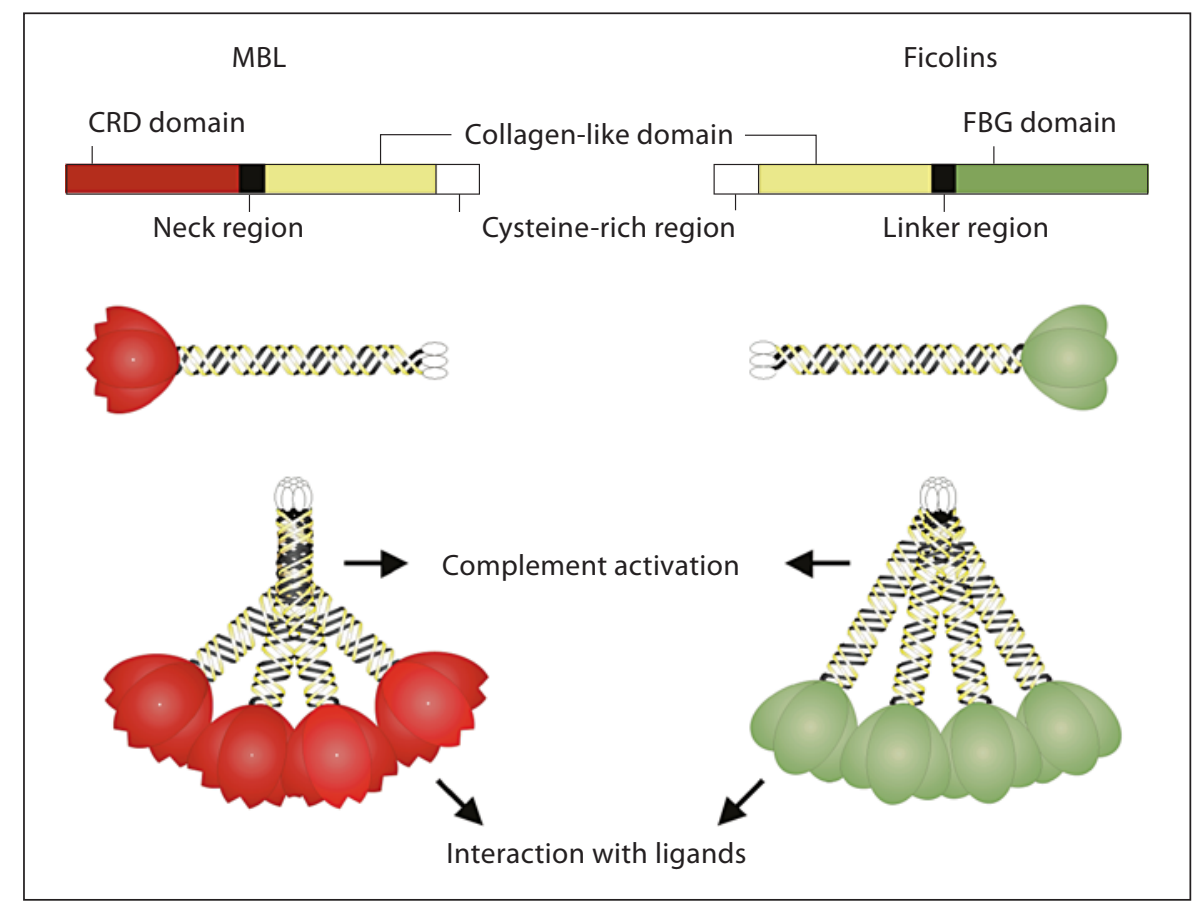

mentatus contains lectins called tachylectins $5 \mathrm{~A}$ and $5 \mathrm{~B}$ [43], which have a C-terminal fibrinogen-like domain that is highly homologous to the ficolins. The tachylectins bind and agglutinate Gram-negative and Gram-positive bacteria indicating the important role of the FBG domain in innate immunity.

The details of the recognition domains of the ficolins have recently been resolved based on the crystal structures of the FBG domains [44, 45; see also review by Garlatti et al. in this issue, pp 17-23]. Surprisingly, ficolin-2 has 4 distinct binding sites whereas only 1 domain is detected in ficolins 1 and 3. Ficolin-2 may therefore have a broader binding specificity than the other ficolins.

\section{Genetics of the Ficolins}

Three ficolin genes have been identified in humans: FCN1, FCN2 and FCN3, which encode ficolin-1, ficolin-2 and ficolin-3, respectively. FCN1 and FCN2 are arranged back-to-back on chromosome 9q34. The exon organisations of FCN1 and FCN2 are similar although FCN1 contains 9 exons instead of 8 , as found in FCN2 [12]. The extra exon encodes an additional segment of 4 Gly-XaaYaa repeats. Exon 1 of the FCN2 encodes the 5' UTR, the leading peptide and a small segment of $\mathrm{N}$-terminal amino acids. Exons 2 and 3 encode the collagen-like domain. The fourth exon encodes the linker region and exons 5-8 encode the FBG domain. The last exon also encodes the 3' UTR [12]. FCN3 has been mapped to chromosome 1p36.11. The FCN3 gene locus is composed of 8 exons and shares the same building structure as seen for FCN1 and FCN2.

To get further insight into evolutionary relationships of the ficolin genes we have generated a neighbour-joining phylogenetic tree using sequences from the National Center for Biotechnology Information Entrez databases. Additional ficolin sequences were identified using Homo sapiens as reference sequence for Basic Local Alignment Search Tool (BLAST) searches of the Ensembl Genomic Database Browser. The entire amino acid sequences were aligned in the program BioEdit using ClustalW with default settings [46]. The alignments were thereafter edited manually in order to remove poorly aligned residue ranges and sequences. The concatenated ficolin alignments were put into the Phylogenetic Web Repeater (POWER) to generate a neighbour-joining tree. The neighbour joining was bootstrapped 1,000 times. Based on several output files, a representative phylogenetic tree was constructed (fig. 2). Additionally, the homology between the ficolins in different species was investigated by pairwise 
Fig. 2. Phylogenetic neighbour-joining tree of the ficolin protein family. The tree was constructed based on the alignments of the entire amino acid sequence of the ficolins using the ClustalW programme. Sequences were obtained from the NCBI Entrez databases and Ensembl Genome Database.

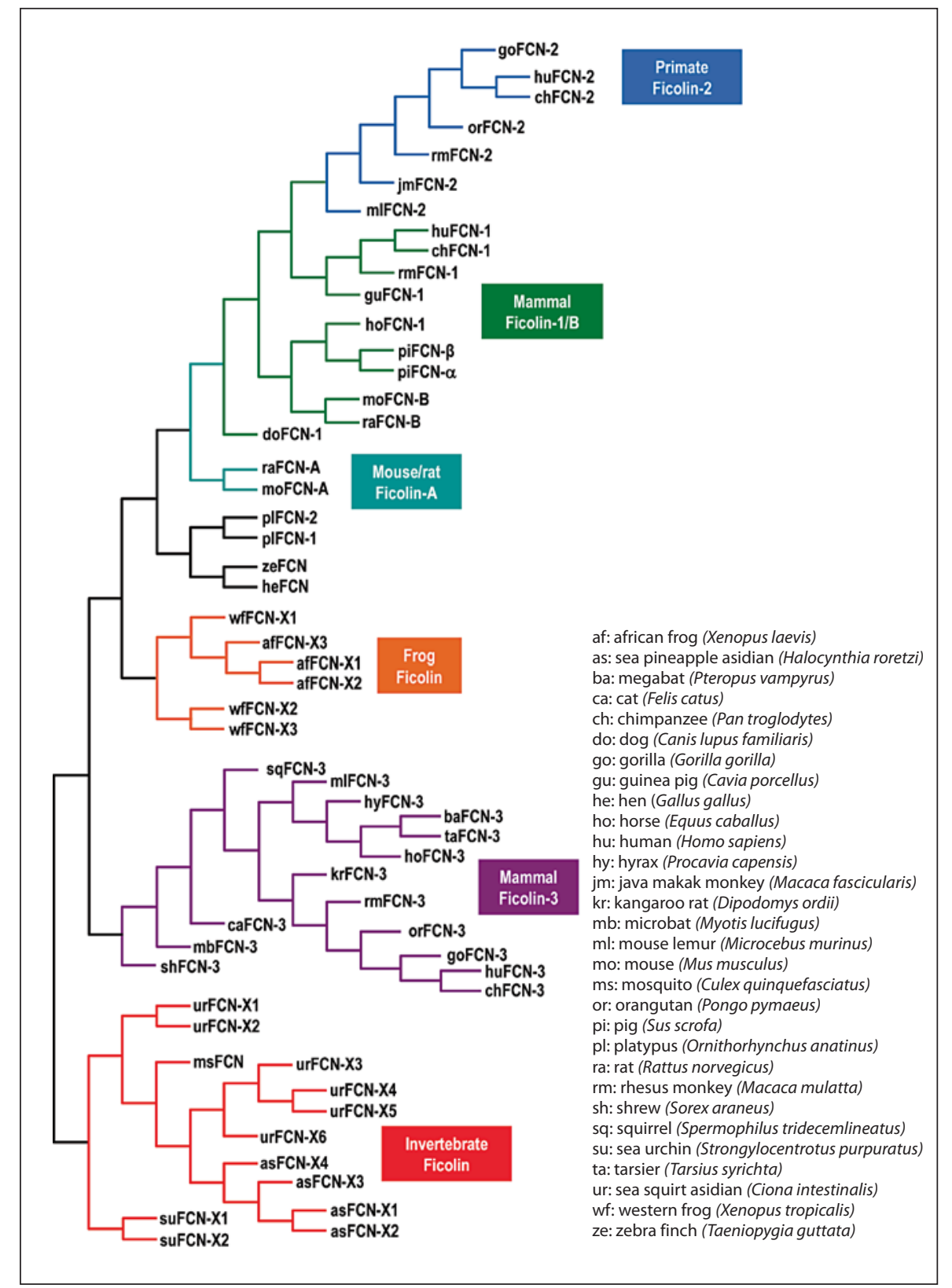

alignment of the amino acid sequences without signal peptide (fig. 3).

The phylogenetic analysis suggests that the mammal FCN3 gene branched out by gene duplication in early vertebrate evolution. The same view has previously been suggested by Kakinuma et al. [17]. Based on this tree, the origin of ficolin-3 goes back to the evolutionary stage before the divergence of frogs. The frog and invertebrate ficolins each form tight clusters of several ficolins. Based on pairwise amino acid homology-analyses, none of the ficolins in either frog or invertebrates can be directly related to any of the human ficolins. Based on sequences in the databases, orthologs of human ficolin-3 were found in both higher and lower primates, as well as species such as the shrew, squirrel, bat and cat (fig. 2). Nevertheless, in both mouse and rat, FCN3 ( $\left.f_{c n} 3\right)$ has been identified as a pseudogene [47]. Therefore, it is reasonable to assume that the inactivation of the gene has arisen after branching of the rodent lineages, since both higher and lower primates relative to the mice and rat species have an in- 


\begin{tabular}{|c|c|c|c|c|c|c|c|c|c|c|c|c|c|c|c|c|c|c|c|}
\hline & $\begin{array}{l}\sum_{0} \\
\vdots \\
\vdots\end{array}$ & 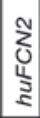 & $\begin{array}{l}0 \\
0 \\
\text { L } \\
\text { s. }\end{array}$ & $\begin{array}{l}\sum \\
0 \\
\text { L } \\
0 \\
0\end{array}$ & $\begin{array}{l}\text { No } \\
\text { L } \\
\text { U. }\end{array}$ & 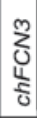 & $\begin{array}{l}\sum_{0} \\
\text { L } \\
\text { E }\end{array}$ & $\begin{array}{l}\sum_{\text {O }} \\
\text { है }\end{array}$ & 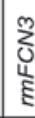 & 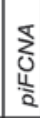 & 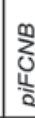 & $\begin{array}{l}\sum_{0}^{5} \\
\text { L } \\
0\end{array}$ & \begin{tabular}{|l}
0 \\
0 \\
0 \\
d \\
0
\end{tabular} & 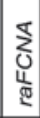 & 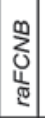 & $\begin{array}{l}5 \\
\text { ડ } \\
4 \\
0 \\
\text { है }\end{array}$ & $\begin{array}{l}\sum_{0} \\
0 \\
\bigsqcup \\
0 \\
\text { है }\end{array}$ & 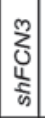 & $\begin{array}{l}0 \\
0 \\
4 \\
4 \\
5\end{array}$ \\
\hline huFCN1 & & 81 & 47 & 98 & 80 & 46 & 91 & 81 & 39 & 77 & 81 & 81 & 46 & 60 & 79 & 60 & 76 & 46 & 44 \\
\hline huFCN2 & & & 49 & 81 & 98 & 48 & 81 & 94 & 41 & 78 & 77 & 75 & 51 & 60 & 72 & 59 & 70 & 48 & 47 \\
\hline huFCN3 & & & & 48 & 50 & 98 & 44 & 46 & 81 & 47 & 48 & 46 & 87 & 45 & 47 & 47 & 47 & 76 & 82 \\
\hline chFCN1 & & & & & 80 & 46 & 91 & 81 & 39 & 77 & 82 & 81 & 47 & 61 & 79 & 62 & 76 & 46 & 44 \\
\hline chFCN2 & & & & & & 48 & 80 & 93 & 40 & 77 & 76 & 74 & 51 & 59 & 71 & 59 & 69 & 47 & 46 \\
\hline chFCN3 & & & & & & & 43 & 46 & 80 & 45 & 44 & 46 & 83 & 42 & 44 & 43 & 44 & 76 & 82 \\
\hline ImFCN1 & & & & & & & & 81 & 38 & 77 & 80 & 78 & 44 & 59 & 77 & 59 & 74 & 45 & 44 \\
\hline $\mathrm{rmFCN} 2$ & & & & & & & & & 40 & 79 & 78 & 74 & 47 & 59 & 73 & 59 & 71 & 48 & 46 \\
\hline ImFCN3 & & & & & & & & & & 40 & 39 & 41 & 78 & 38 & 40 & 39 & 41 & 67 & 75 \\
\hline piFCNA & & & & & & & & & & & 82 & 75 & 48 & 59 & 74 & 59 & 72 & 47 & 45 \\
\hline piFCNB & & & & & & & & & & & & 80 & 49 & 61 & 79 & 60 & 77 & 47 & 45 \\
\hline hoFCN1 & & & & & & & & & & & & & 46 & 59 & 76 & 59 & 75 & 47 & 46 \\
\hline hoFCN3 & & & & & & & & & & & & & & 45 & 48 & 46 & 47 & 78 & 84 \\
\hline raFCNA & & & & & & & & & & & & & & & 61 & 89 & 60 & 41 & 43 \\
\hline raFCNB & & & & & & & & & & & & & & & & 61 & 89 & 47 & 45 \\
\hline moFCNA & & & & & & & & & & & & & & & & & 60 & 43 & 43 \\
\hline moFCNB & & & & & & & & & & & & & & & & & & 45 & 44 \\
\hline hFCN3 & & & & & & & & & & & & & & & & & & & \\
\hline FCN3 & & & & & & & & & & & & & & & & & & & \\
\hline
\end{tabular}

Fig. 3. Pairwise identity alignment of the ficolins. The homology among the ficolins in different species was investigated by pairwise alignment of the amino acid sequences without signal peptides. hu = Human; $\mathrm{ch}=$ chimpanzee; $\mathrm{rm}=$ rhesus monkey; $\mathrm{pi}=$ pig; ho = horse; $\mathrm{ra}=$ rat; $\mathrm{mo}=$ mouse; $\mathrm{sh}=$ shrew $\mathrm{kr}=$ kangaroo rat.

tact FCN3 gene. However, it is at present only in the human situation that ficolin-3 has been purified and characterised. Whether differences between $F C N 3$ promoter sequences and differences in regulatory mechanisms between species may affect relative expression and protein translation of ficolin-3 remains to be elucidated.

The phylogenetic tree demonstrates that the ficolin precursor has gone through an expansion involving additional duplication events during evolution. Several species seem to have duplicated the ficolin precursor gene independently. The pairwise alignment of the amino acid sequence suggest that the mouse and rat ficolin-B is the orthologue of the human ficolin-1, with identities of 76 and $79 \%$, respectively. Alignment of the human ficolin-1 protein with ficolins from other species shows that ficolin-1 is present in several species such as primates (ficolin-1), pig (ficolin- $\beta$ ), horse (ficolin-2), dog (ficolin-1), mouse (ficolin-B) and rat (ficolin-B). All of these ficolins show high amino acid homology $(>76 \%)$. In addition, humans and pigs have an extra ficolin protein that is also homologous to the common 'ficolin-1'. These proteins are called ficolin-2 or L-ficolin and ficolin- $\alpha$, respective- ly. The ortholog of the human ficolin-2 was only observed in higher and lower primates, suggesting that the ficolin2 gene diverged after branching of the mouse and primate lineages. Also, pigs seem to have duplicated their genes independently, since they cluster within the species. In general, the exon organisation of the different ficolins shows highly homologous structures. Most of the primary amino acid sequences in all the mammal ficolins align well. However, the amino acid sequence located in exons 4-6 (relative to the mouse ficolin-A) varies greatly among the ficolins (fig. 4). This region corresponds to exons 4 and 5 in mouse ficolin-B and human ficolin-1, and exon 4 of the human ficolin-2. When this stretch of 36 amino acids of the mouse ficolin-A is aligned to all other ficolins, it is clear that the human ficolin-1 corresponds to the mouse ficolin-B. Furthermore, this alignment illustrates that the mouse and rat ficolin-A constitute a separate group of proteins. Additionally, the primate ficolin-2 also seems to form its own ficolin group, supporting the analysis above. Based on these observations, it is therefore likely that 'ficolin-1' is a true orthologue that is present in all higher mammals, whereas the primate ficolin-2 and pig ficolin- $\alpha$, as well as mouse and rat ficolin-A are the result of independent gene duplications in the different species. This implies that some mammals or mammal families have independently duplicated their 'ficolin-1' (FCN1) gene probably due to selection forces operating at different time periods. It remains to be established how pronounced this form for duplication of the 'ficolin-1' gene is in different species.

\section{Tissue Expression}

The FCN1 gene is primarily expressed in peripheral blood leukocytes and in bone marrow-derived cells although minor expression is also observed in the spleen and the lung [26]. This is in agreement with studies showing that ficolin-1 is present in monocytes and weakly present in the spleen and type II alveolar cells in the lung $[8,19,22,25,48]$. It has been shown by real-time PCR examination of normal human bone marrow that FCN1 is expressed largely in myelocytes, metamyelocytes and band cells with a profile quite similar to that of gelatinase [49]. In accordance with this, confocal microscopy and subcellular fractionation demonstrated that ficolin-1 is primarily localized in gelatinase granules of neutrophils, but also in highly exocytosable gelatinase poor granules not previously described [49]. The protein is released from neutrophil granules by stimulation with fMLP or 


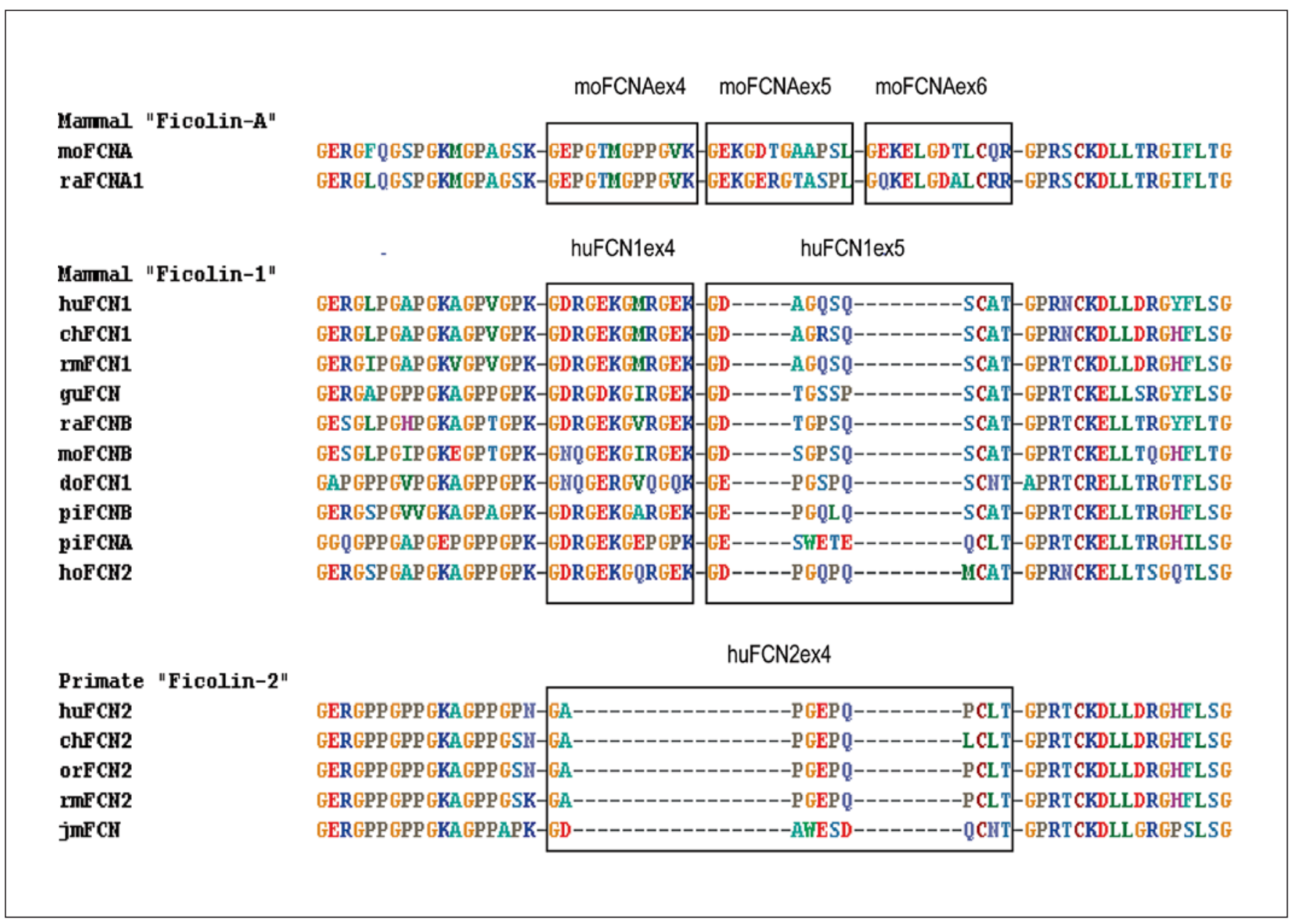

Fig. 4. Alignment of the mouse ficolin-A exons 4-6 with other ficolins. The amino acid sequence of exons 4-6 (relative to the mouse ficolin-A) in different species was aligned with mouse ficolin-A as reference sequence. This alignment shows that mouse and rat ficolin-A are different from the other ficolins. Furthermore, many of the known mammalian ficolins (except for ficolin-
3) must be considered as 'ficolin-1' related proteins. The primate ficolin-2 seems to represent a separate group of ficolins. mo = Mouse; $\mathrm{ra}=\mathrm{rat}$; hu = human; $\mathrm{ch}=$ chimpanzee; $\mathrm{rm}=$ rhesus monkey; gu = guinea pig; do = dog; $\mathrm{pi}=$ pig; ho = horse; $\mathrm{jm}=$ java macaque monkey.
PMA, but the majority (90\%) becomes associated with the surface membrane of the cells. Altogether the neutrophils appear to be a major source and reservoir of ficolin1. Ficolin-1 is also found in human serum and plasma, but the real concentration in healthy individuals is still a matter of debate, since we found a median concentration of $0.06 \mu \mathrm{g} / \mathrm{ml}$ (range $0.04-0.1 \mu \mathrm{g} / \mathrm{ml}$ ) in a limited number of healthy donors [22], while a more recent study showed that the median concentration in a larger group of donors was around $1 \mu \mathrm{g} / \mathrm{ml}$ (range $0.28-4 \mu \mathrm{g} / \mathrm{ml}$ ) [50]. Whether this reflects true biological differences or assay or sampling differences remains to be elucidated. Nevertheless, both studies suggest that ficolin-1 may play a role as a secreted molecule of importance for local and systemic immune defence.

FCN2 is expressed mainly in the liver [10, 26]. Very low mRNA FCN2 levels may also be detected in the bone marrow, in tonsils, in the intestine and in the foetal lung [26]. It is, however, unknown whether these expression patterns are also translated into ficolin-2 synthesis. Ficolin-2 is found with a median serum/plasma concentration in Caucasians of around $5 \mu \mathrm{g} / \mathrm{ml}$, but with inter-individual variations ranging from $1-12 \mu \mathrm{g} / \mathrm{ml}$ [27-31].

FCN3 is expressed mainly in the liver and the lung, but lower expression is also observed in the heart, kidney, spleen, pancreas and placenta [26]. Ficolin-3 is the most 
abundant of the 3 ficolins in serum, where it is found with a median concentration of $25 \mu \mathrm{g} / \mathrm{ml}$ (range 3-54 $\mu \mathrm{g} / \mathrm{ml}$ ) $[38,51,52]$. Of particular interest is the observation that the expression of FCN3 in the lung exceeds that in the liver, suggesting a role of this protein in lung defence and tissue homeostasis along with the classical collagen-like lung defence proteins SP-A and SP-D [26]. Whether ficolin-3 also has a function in the pulmonary surfactant system remains to be elucidated. A low mRNA level was also detected in brain tissue, which is in agreement with a study showing FCN3 expression in a human glioma cell line [53]. Thus, the 3 human FCNs seem to differ also with respect to their pattern of expression in various tissues, suggesting that these molecules play distinct physiological roles in different organs [35].

\section{Variation in FCN Genes}

Common genetic variations in the MBL gene (MBL2) affecting both the expression and structure of MBL have been studied extensively [54]. These genetic variations have in numerous studies been reported to be associated with different diseases [55]. Although the penetrance of $M B L 2$ genetic variation as a single parameter is debated, it is generally accepted that the presence of $M B L 2$ variant alleles is associated with increased risk of infections in individuals with accompanying comorbidity. More recently it has also been documented that highly expressing MBL2 alleles and high MBL serum concentrations may be associated with adverse effects [56-58]. Thus, because of the similarities between MBL and the ficolins, systematic sequencing studies of the variation in the FCN genes in different ethnic groups have been performed $[28,59$, 60].

\section{The FCN1 Gene}

A large number of genetic variants with large race-related differences have been observed in the FCN1 gene (table 1) [60]. Four FCN1 exon variations result in amino acid substitutions (Gly43Asp, Arg93Gln, Trp279Stop, and Gly303Ser). Only 1 association study of FCN1 polymorphisms has been published so far. This shows that 2 SNPs, which are in complete linkage disequilibrium - 1 in the promoter region and 1 synonymous SNP in exon 9 - are found with increased frequency in 2 different rheumatoid arthritis cohorts compared with controls [61]. The SNPs were not associated with the well-established HLA shared epitopes, rheumatoid factor or the presence of anti-citrullinated IgG antibodies. Still, we lack informa- tion about the putative functional importance of FCN1 polymorphisms. Recently, an interesting study was published showing that premature children with adverse outcome of necrotising enterocolitis had significantly lower levels of ficolin-1 than survivors [62]. Moreover, infants with low ficolin-1 required more frequent assisted ventilation than those with high ficolin-1 levels. Whether these observations can be attributed to inter-individual genetic differences remains to be established.

\section{The FCN2 Gene}

A number of DNA variations have been observed in the FCN2 gene (table 2) [60]. Three single base substitution polymorphisms in positions $-986,-602$ and -4 , respectively, are associated with variation serum concentration of ficolin-2, while 2 other polymorphisms situated in positions -557 and -64 appear not to have a significant impact on the serum concentration of ficolin$2[28,31,63]$. Nevertheless, data showing the functional impact of these polymorphisms are lacking. In addition, several polymorphisms resulting in amino acid changes have been observed in the coding part of the FCN2 gene (table 2). Some of these polymorphisms are specific for different ethnic groups while others are broadly distributed [60]. After the original report of the FCN2 polymorphisms [28], some of the FCN2 variants have also been demonstrated in Dutch, Japanese, Polish, English and Brazilian populations [59, 63-66]. Of particular interest are two FCN2 amino acid substituting SNPs located in exon 8 encoding the FBG domain (Thr236Met and Ala258Ser) [28]. When serum from individuals homozygous for the wild type and the Thr236Met and Ala258Ser variants, was incubated with solid phase or soluble GlcNAc, great differences in their ability to bind to GlcNAc were observed [28] (fig. 5). The Ala258Ser variant showed elevated binding capacity compared to wild type, whereas variant Thr236Met exhibited reduced binding capacity. Similar results were observed in followup studies when wild type ficolin-2 and the Thr236Met variant produced in $\mathrm{CHO}$ cells where employed [67]. The observed SNPs are likely to cause specific alterations of the FBG domain, thus affecting the binding to ligands, but they are not located in the observed FBG binding sites that have been deduced based on crystallographic observations [44]. Two well-conducted studies have explored the putative importance of the FCN2 polymorphisms and the possible importance in invasive pneumococcal disease in adults and self reported respiratory infections in children $[65,68]$, but no significant associations were observed. Rheumatic fever and chronic rheumatic heart 
Table 1. Polymorphisms identified in the FCN1 gene. Positions of polymorphisms are counted with respect to the FCN1 translation start site with the A of ATG being +1 and the 5 '-following base being -1

\begin{tabular}{|c|c|c|c|c|c|c|c|c|c|}
\hline $\begin{array}{l}\text { Base } \\
\text { position }\end{array}$ & $\begin{array}{l}\text { Major } \\
\text { allele }\end{array}$ & $\begin{array}{l}\text { Minor } \\
\text { allele }\end{array}$ & $\mathrm{dbSNP}$ & Region & $\begin{array}{l}\text { Amino } \\
\text { acid change }\end{array}$ & \multicolumn{4}{|c|}{ Minor allele frequency } \\
\hline-1233 & $\mathrm{~A}$ & $\mathrm{C}$ & rs56092718 & promoter & - & 0.00 & 0.00 & 0.05 & 0.00 \\
\hline-1180 & $\mathrm{G}$ & $\mathrm{T}$ & rs7022634 & promoter & - & 0.00 & 0.26 & 0.24 & 0.00 \\
\hline-881 & $\mathrm{G}$ & A & rs56402344 & promoter & - & 0.00 & 0.06 & 0.03 & 0.00 \\
\hline-756 & $\mathrm{C}$ & $\mathrm{T}$ & rs3762083 & promoter & - & 0.00 & 0.00 & 0.00 & 0.01 \\
\hline-755 & $\mathrm{G}$ & A & rs56225434 & promoter & - & 0.00 & 0.18 & 0.22 & 0.00 \\
\hline-631 & $\mathrm{G}$ & $\mathrm{A}$ & rs55889197 & promoter & - & 0.00 & 0.00 & 0.01 & 0.00 \\
\hline-582 & $\mathrm{C}$ & $\mathrm{T}$ & rs17039501 & promoter & - & 0.00 & 0.15 & 0.20 & 0.00 \\
\hline-542 & $\mathrm{G}$ & A & rs10120023 & promoter & - & 0.31 & 0.14 & 0.06 & 0.06 \\
\hline-523 & $\mathrm{~T}$ & $\mathrm{C}$ & rs56005457 & promoter & - & 0.00 & 0.01 & 0.01 & 0.00 \\
\hline-210 & $\mathrm{G}$ & $\mathrm{Dg}$ & rs56036264 & promoter & - & 0.00 & 0.00 & 0.01 & 0.00 \\
\hline-205 & $\mathrm{G}$ & $\mathrm{C}$ & rs28909977 & promoter & - & 0.00 & 0.00 & 0.00 & 0.00 \\
\hline-160 & $\mathrm{C}$ & G & rs56077839 & promoter & - & 0.00 & 0.04 & 0.02 & 0.00 \\
\hline-144 & $\mathrm{C}$ & $\mathrm{A}$ & rs10117466 & promoter & - & 0.34 & 0.12 & 0.06 & 0.00 \\
\hline-64 & $\mathrm{C}$ & $\mathrm{T}$ & rs55712611 & promoter & - & 0.00 & 0.01 & 0.00 & 0.00 \\
\hline+33 & $\mathrm{G}$ & $\mathrm{T}$ & rs10858293 & exon 1 & Gly11Gly & 0.33 & 0.27 & 0.28 & 0.06 \\
\hline+116 & $\mathrm{~T}$ & G & rs56330318 & intron 1 & - & 0.00 & 0.00 & 0.01 & 0.00 \\
\hline+184 & $\mathrm{C}$ & $\mathrm{T}$ & rs56045618 & intron 1 & - & 0.00 & 0.01 & 0.00 & 0.00 \\
\hline+1435 & $\mathrm{G}$ & A & rs10441778 & exon 2 & Gly43Asp & 0.00 & 0.07 & 0.02 & 0.00 \\
\hline+1538 & $\mathrm{G}$ & A & rs55871507 & intron 2 & - & 0.00 & 0.01 & 0.00 & 0.00 \\
\hline+3144 & $\mathrm{C}$ & $\mathrm{T}$ & rs56329856 & intron 3 & - & 0.00 & 0.01 & 0.01 & 0.00 \\
\hline+3164 & $\mathrm{G}$ & $\mathrm{A}$ & rs7863062 & intron 3 & - & 0.00 & 0.17 & 0.20 & 0.00 \\
\hline+4356 & $\mathrm{C}$ & $\mathrm{T}$ & rs55862654 & intron 5 & - & 0.00 & 0.17 & 0.22 & 0.00 \\
\hline+4408 & $\mathrm{C}$ & A & rs55894555 & intron 5 & - & 0.00 & 0.17 & 0.13 & 0.00 \\
\hline+4410 & $\mathrm{C}$ & $\mathrm{dC}$ & rs11297508 & intron 5 & - & 0.00 & 0.33 & 0.24 & 0.00 \\
\hline+4473 & $\mathrm{~T}$ & $\mathrm{C}$ & rs55743915 & intron 5 & - & 0.00 & 0.00 & 0.03 & 0.00 \\
\hline+4701 & $\mathrm{G}$ & $\mathrm{A}$ & rs55806386 & intron 5 & - & 0.00 & 0.01 & 0.00 & 0.00 \\
\hline+4888 & $\mathrm{G}$ & $\mathrm{C}$ & rs2070622 & intron 6 & - & 0.34 & 0.06 & 0.12 & 0.58 \\
\hline+5358 & $\mathrm{C}$ & $\mathrm{T}$ & rs2274845 & exon 7 & Asn190Asn & 0.37 & 0.06 & 0.11 & 0.57 \\
\hline+5370 & $\mathrm{C}$ & $\mathrm{T}$ & rs56308117 & exon 7 & His $194 \mathrm{His}$ & 0.00 & 0.01 & 0.00 & 0.00 \\
\hline+7918 & $\mathrm{G}$ & A & rs1071583 & exon 9 & Gln275Gln & 0.37 & 0.01 & 0.06 & 0.56 \\
\hline+7929 & $\mathrm{G}$ & $\mathrm{A}$ & rs56094122 & exon 9 & Trp279Stop & 0.00 & 0.00 & 0.02 & 0.00 \\
\hline+8000 & $\mathrm{G}$ & A & rs56151153 & exon 9 & Gly303Ser & 0.00 & 0.01 & 0.00 & 0.00 \\
\hline
\end{tabular}

DNK = Denmark; MOZ = Mozambique; GHA = Ghana; JPN = Japan; $\mathrm{n}=$ number of individuals analysed. 
Table 2. Polymorphisms identified in the FCN2 gene. Positions of polymorphisms are counted with respect to the FCN2 translation start site with the A of ATG being +1 and the $5^{\prime}$-following base being -1

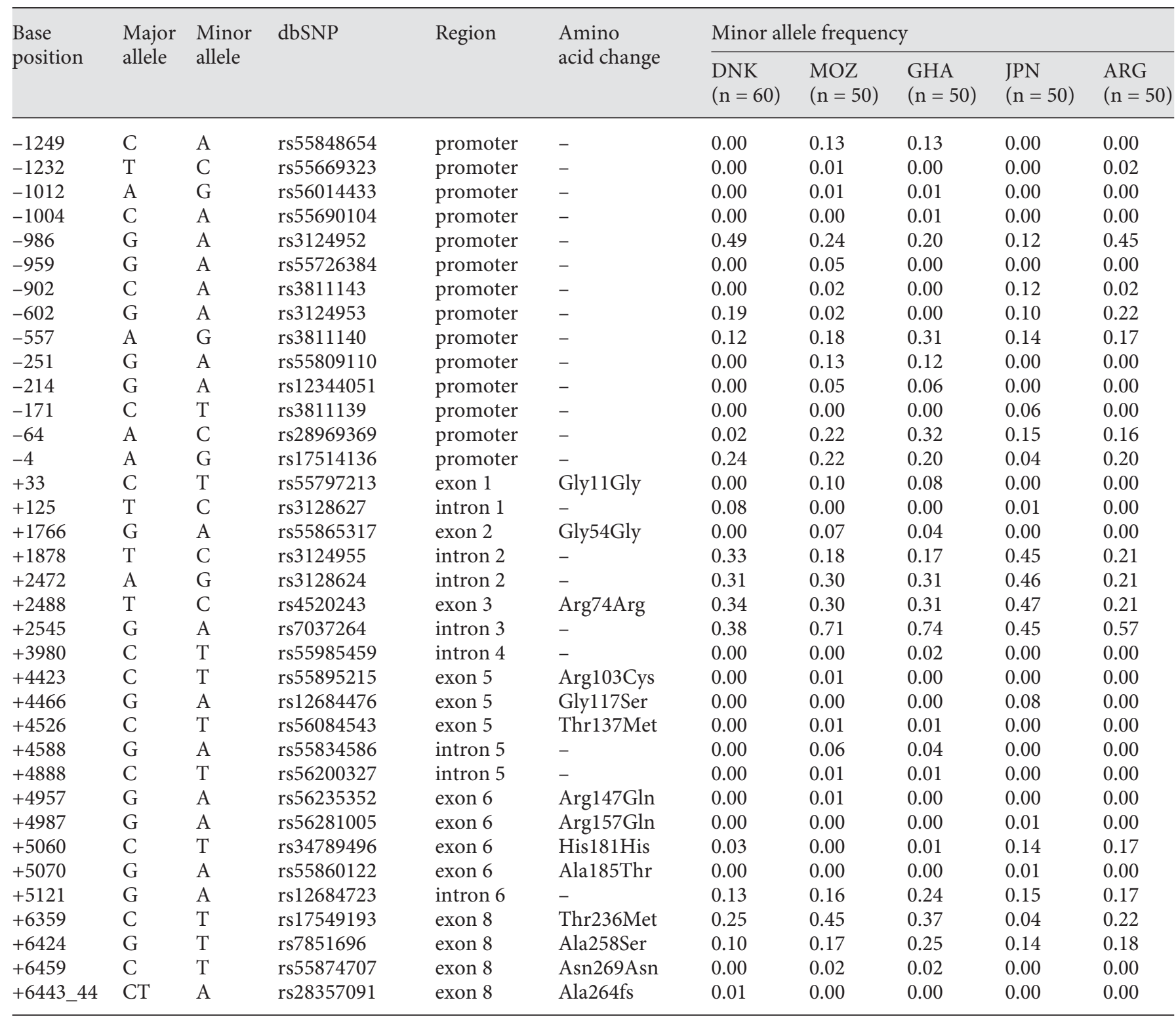

DNK = Denmark; MOZ = Mozambique; GHA = Ghana; JPN = Japan; ARG = Argentina; $\mathrm{n}=$ number of individuals analysed .

disease has been investigated for association with promoter polymorphisms in the FCN2 gene [69]. These latter results show that the FCN2 haplotype (-986/-602 and -4 $\mathrm{G} / \mathrm{G} / \mathrm{A}$ ) that is associated with the lowest ficolin-2 serum [31] is also associated with chronic rheumatic heart disease. Conversely, a protective effect of an FCN2 haplotype associated with higher ficolin-2 serum levels has been observed in relation to clinical leposy [66]. Although, these findings are very interesting, they need to be confirmed in independent studies and the possible biological mechanisms remain to be elucidated.

\section{The FCN3 Gene}

Only few DNA variations have been detected in FCN3 including 5 amino acid exchanging variants (table 3) [60]. All of the variations are present in very low frequencies.

Investigations of serum from several hundred thousand individuals show that ficolin-3 deficiency is a rare 


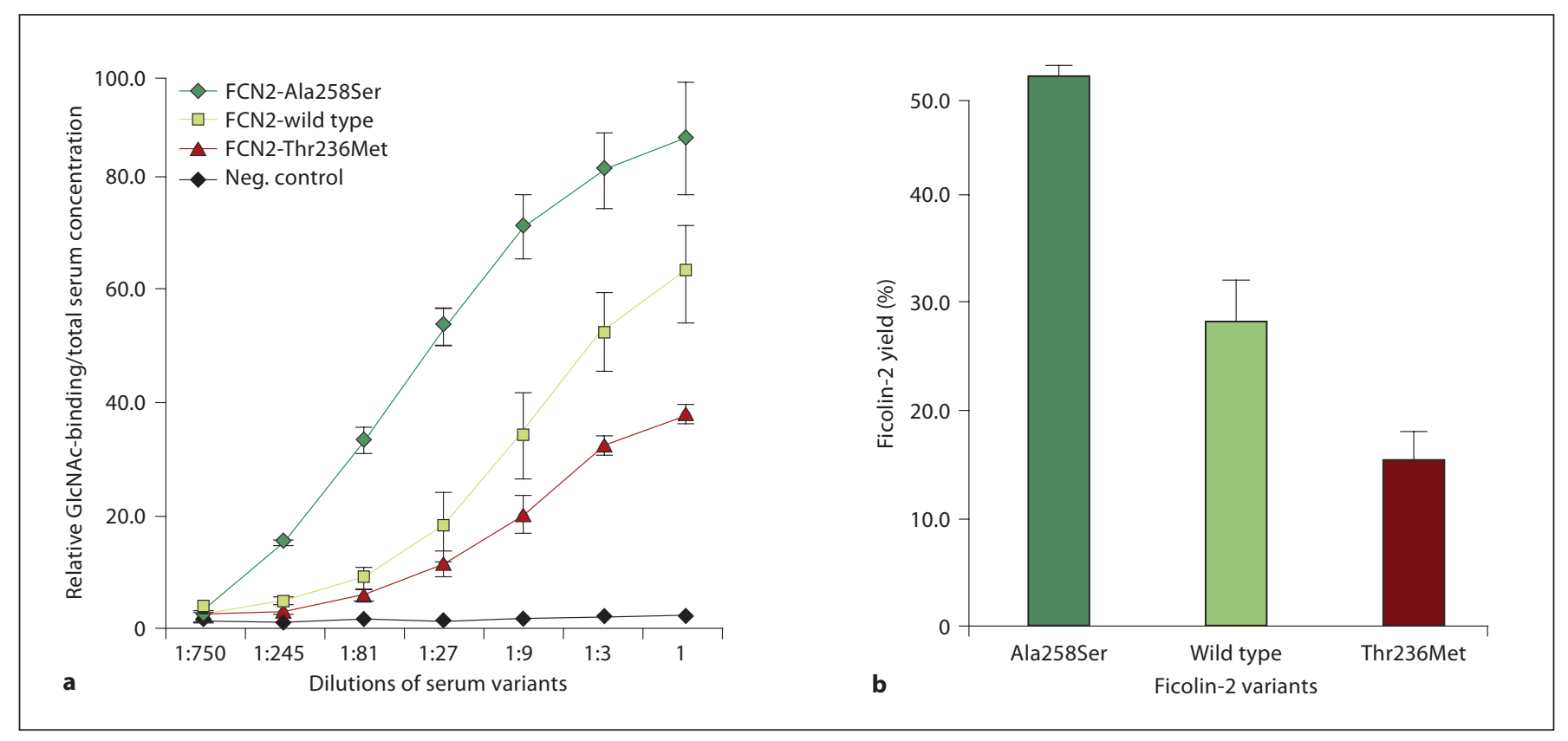

Fig. 5. Binding of ficolin-2 variants to GlcNAc. a Dilutions of human serum representing ficolin-2 variants were added to GlcNAccoated ELISA wells and bound ficolin-2 was measured. GlcNAcbinding is given as index values based on OD values $(490 \mathrm{~nm})$ from the GlcNAc-ELISA assay divided with the ficolin-2 concentration in the full serum samples $(\mathrm{mg} / \mathrm{l})$ in order to compensate for sample differences in ficolin-2 concentrations. A difference in binding profile towards GlcNAc was observed for the investigated ficolin-2 variants wild type, Thr236Met and Ala258Ser, respectively, indicating changed functionality due to the polymorphisms. Each graph represents the average of 3 individuals with identical genotype. Standard error of the mean is indicated. No binding was observed to BSA (negative control). b Human serum variants were incubated with GlcNAc-agarose beads and ficolin-2 was eluted with GlcNAc. Ficolin-2 concentrations were measured in ELISA in full serum and eluates from ficolin-2-purified samples, and the purification yield was subsequently determined. The Ala258Ser variant showed a marked increase in binding capacity towards GlcNAc compared to the wild type and Thr236Met variants. Each bar represents 3 individuals. Standard error of the mean is indicated. Adapted from [28]. condition. Ficolin-3 was found in all of the sera from more than 10,000 Japanese blood donors and in virtually all sera from several 100,000 Japanese patients [33]. However, a frame-shift variation Leu117fs in exon 5 of the FCN3 gene in position FCN3+1637 (rs28357092) has been observed [28]. This variant may be found in healthy Caucasian and African populations, with an allele frequency of 0.01 and 0.04 , respectively [52]. The variant causes a reading frame shift and an altered amino acid composition of the C-terminal end of ficolin-3, spanning from amino acid position 117 to position 180, where the nonsense protein sequence is terminated due to an early stop codon (fig. 6). Theoretically, this causes a truncated ficolin-3 variant (Leu117fs) lacking 183 amino acids of the sequence corresponding to the entire FBG domain. Nevertheless, experiments with recombinant ficolin-3 containing the Leu117fs variant show that the variant protein cannot be expressed and would therefore most likely lead to complete ficolin-3 deficiency in vivo [52]. To further substantiate these seminal findings, we screened 1,282 patients with suspected primary immunodeficiency for the FCN3delC+1637 Leu117fs variant [70]. We found that $1.8 \%$ were heterozygous, which is the same frequency as in the healthy population, while 1 patient was homozygous. The index patient suffered from severe unexplained recurrent bacterial lung infections, bronchiectasis, lung fibrosis and obstructive lung disease and had experienced cerebral abscesses. In addition, the patient had undergone splenectomy due to unexplained thrombocytopenia. He also had large warts on his fingers. In the patients investigated, the median ficolin-3 serum concentration in wild types was $27.5 \mu \mathrm{g} / \mathrm{ml}$ (range $3.5-42.6 \mu \mathrm{g} / \mathrm{ml}$ ) while it was $14.1 \mu \mathrm{g} / \mathrm{ml}$ (range $8.0-31.4 \mu \mathrm{g} / \mathrm{ml}$ ) in FCN3delC +1637 heterozygotes, showing that heterozygous carriers may in general have a $50 \%$ reduction in ficolin-3 serum concentration. No ficolin-3 antigen could 
Fig. 6. Illustration of ficolin-3 structure and the effect of FCN3+1637delC frameshift variation. The upper panel shows a model of the oligomerisation into higher orders and the domains of the ficolin-3 monomer structure in wild type and the mutated polypeptide. Exon regions of FCN3 are marked with black vertical lines. The FCN3+1637delC_(L117fs) frame shift (fs) variant (mutation) is represented by a red dot. Adapted from [70].

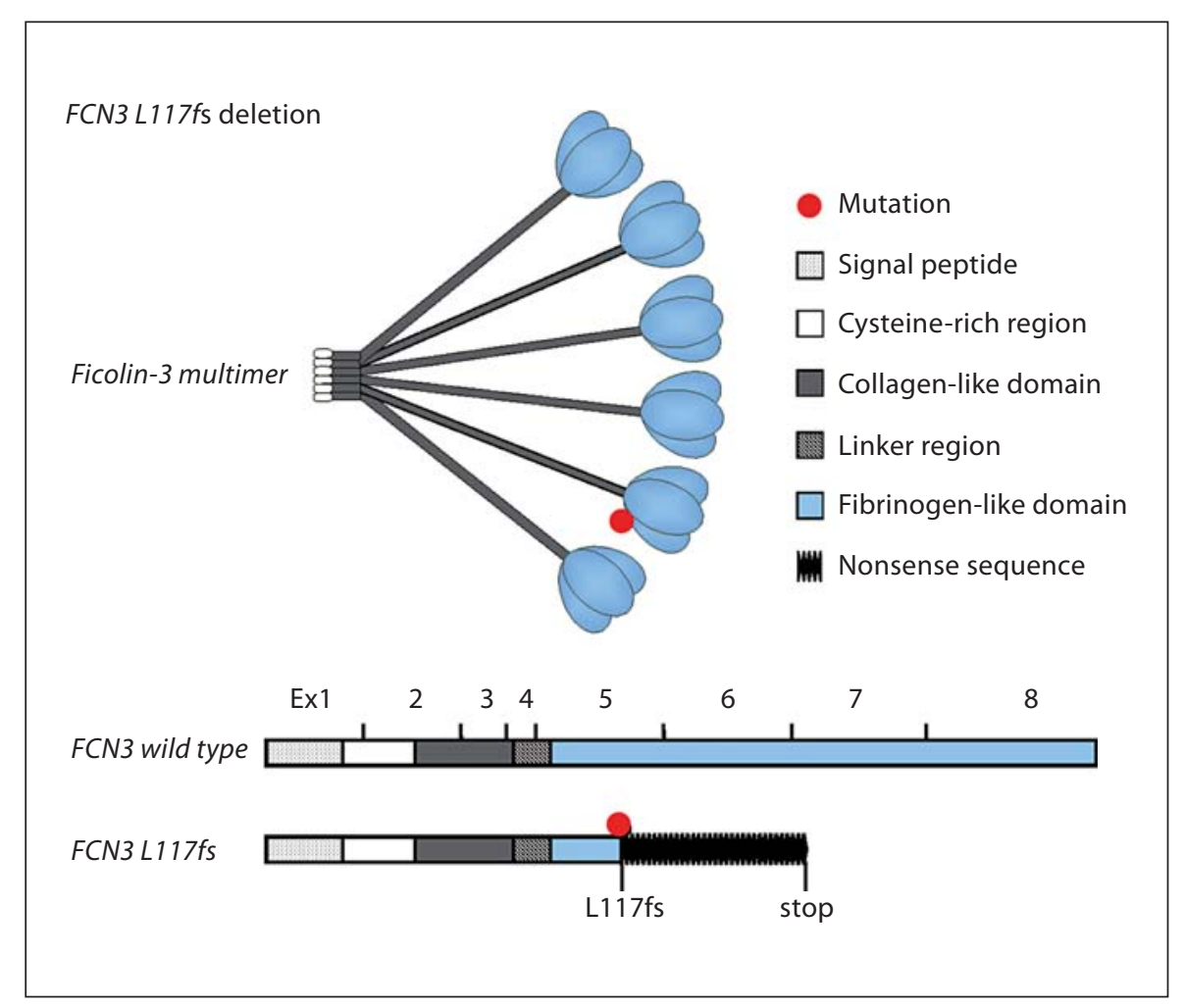

Table 3. Polymorphisms identified in the FCN3 gene. Positions of polymorphisms are counted with respect to the FCN3 translation start site with the A of ATG being +1 and the $5^{\prime}$-following base being -1

\begin{tabular}{|c|c|c|c|c|c|c|c|c|c|}
\hline $\begin{array}{l}\text { Base } \\
\text { position }\end{array}$ & $\begin{array}{l}\text { Major } \\
\text { allele }\end{array}$ & $\begin{array}{l}\text { Minor } \\
\text { allele }\end{array}$ & dbSNP & Region & $\begin{array}{l}\text { Amino acid } \\
\text { change }\end{array}$ & $\begin{array}{l}\text { DNK } \\
(n=60)\end{array}$ & $\begin{array}{l}\text { MOZ } \\
(n=50)\end{array}$ & $\begin{array}{l}\text { GHA } \\
(n=50)\end{array}$ & $\begin{array}{l}\text { JPN } \\
(n=50)\end{array}$ \\
\hline-954 & $\mathrm{C}$ & $\mathrm{T}$ & rs41465749 & promoter & - & 0.01 & 0.02 & 0.00 & 0.00 \\
\hline-813 & G & A & rs56174383 & promoter & - & 0.00 & 0.01 & 0.00 & 0.00 \\
\hline-608 & G & A & rs28385648 & promoter & - & 0.02 & 0.00 & 0.00 & 0.00 \\
\hline+51 & G & A & rs56088921 & exon 1 & Gly17Gly & 0.00 & 0.00 & 0.01 & 0.00 \\
\hline+1402 & $\mathrm{~T}$ & $\mathrm{C}$ & rs56088921 & intron 4 & - & 0.00 & 0.00 & 0.02 & 0.00 \\
\hline+1549 & $\mathrm{~T}$ & $\mathrm{C}$ & rs28385723 & intron 4 & - & 0.00 & 0.01 & 0.01 & 0.00 \\
\hline+1637 & $\mathrm{C}$ & $\mathrm{dC}$ & rs28357092 & exon 5 & Leu117fs & 0.01 & 0.04 & 0.00 & 0.00 \\
\hline+1663 & A & $\mathrm{G}$ & rs56407240 & exon 5 & Thr125Ala & 0.00 & 0.04 & 0.00 & 0.00 \\
\hline+5543 & $\mathrm{~T}$ & $\mathrm{C}$ & rs55863154 & exon 8 & Val287Ala & 0.00 & 0.01 & 0.00 & 0.00 \\
\hline
\end{tabular}

DNK = Denmark; MOZ = Mozambique; GHA = Ghana; JPN = Japan; $\mathrm{n}=$ number of individuals analysed. 
be detected in the FCN3+1637delC homozygous patient. The structure based on SDS-PAGE and Western blotting appeared the same in wild type and in heterozygotes. Complement deposition on an acetylated compound was absent in ficolin-3 deficient serum, but could be reconstituted with recombinant ficolin-3.

Complement deficiencies are usually associated with increased risk for invasive bacterial infections or for developing autoimmune diseases. The index patient suffered from severe disabling respiratory and intracerebral abscesses. This is in agreement with the high expression of ficolin-3 in the lungs as well as the expression by glioma cells as previously mentioned $[26,35,53]$. The thrombocytopenia may have had an autoimmune origin, but this awaits further characterization. Ficolin-3 has also been shown to be important in sequestration of dying host cells $[71,72]$. It is therefore tempting to speculate that deficiency of ficolin-3 hampers the removal of cellular debris and endogenous waste material, thus aggravating and perpetuating ongoing infectious events and inflammatory processes without being associated with a particular infection per se. Taken together these findings show that genetically determined deficiency of ficolin-3 might cause a novel complement deficiency syndrome. Recently, it has been reported that children with malignancies treated with chemotherapy who had low ficolin-3 serum levels $(<14 \mu \mathrm{g} / \mathrm{ml})$ had more episodes of fever and were more neutropenic than children with higher ficolin3 concentrations [73]. Whether these findings may be linked to heterozygosity for the FCN3+1637delC Leu117fs variant remains to be established. It is, however, striking that the median serum concentration in FCN3+1637delC Leu117fs variant heterozygotes was $14.1 \mu \mathrm{g} / \mathrm{ml}$, which is the ficolin-3 cut off value reported in the chemotherapy study [73].

\section{Concluding Remarks}

It appears from database search and phylogenetic tree analysis that the most ancient ficolin molecule is ficolin3 , which then evolved to the other ficolins. However, each branch of the phylogenetic tree creates new ficolins. Nevertheless, based on in silico analysis it is likely that 'ficolin-1' is a true or tholog protein present in all higher mammals, whereas for instance primate ficolin-2 and pig ficolin- $\alpha$ are the results of independent gene duplications in the different species. The ficolins may be assumed to be involved in the pathophysiology of different infectious and inflammatory diseases. Although the literature in this field is rudimentary, several lines of evidence suggest that polymorphisms or haplotypes in the FCN1 and FCN2 genes may be associated with different diseases. A striking example is the observation that genetically determined deficiency of ficolin-3 might be associated with immunodeficiency in the humans. Identification of FCN variants associated with clinical outcomes is a new and blooming field, which should be thoroughly investigated in the years to come.

\section{References}

1 Akira S, Uematsu S, Takeuchi O: Pathogen recognition and innate immunity. Cell 2006; 124:783-801.

-2 Shaw MH, Reimer T, Kim YG, Nunez G: NOD-like receptors (NLRs): bona fide intracellular microbial sensors. Curr Opin Immunol 2008;20:377-382.

-3 Manfredi AA, Rovere-Querini P, Bottazzi B, Garlanda C, Mantovani A: Pentraxins, humoral innate immunity and tissue injury. Curr Opin Immunol 2008;20:538-544.

4 Kuroki Y, Takahashi M, Nishitani C: Pulmonary collectins in innate immunity of the lung. Cell Microbiol 2007;9:1871-1879.

5 Walport MJ: Complement. First of two parts. N Engl J Med 2001;344:1058-1066.

6 Matsushita M, Endo Y, Fujita T: Cutting edge: complement-activating complex of ficolin and mannose-binding lectin-associated serine protease. J Immunol 2000;164: 2281-2284.
7 Matsushita M, Kuraya M, Hamasaki N, Tsujimura M, Shiraki H, Fujita T: Activation of the lectin complement pathway by $\mathrm{H}$-ficolin (Hakata antigen). J Immunol 2002;168: 3502-3506.

$>8$ Liu Y, Endo Y, Iwaki D, Nakata M, Matsushita M, Wada I, Inoue K, Munakata M, Fujita T: Human M-ficolin is a secretory protein that activates the lectin complement pathway. J Immunol 2005;175:3150-3156.

-9 Sugimoto R, Yae Y, Akaiwa M, Kitajima S, Shibata Y, Sato H, Hirata J, Okochi K, Izuhara K, Hamasaki N: Cloning and characterization of the Hakata antigen, a member of the Ficolin/opsonin p35 lectin family. J Biol Chem 1998;273:20721-20727.
10 Matsushita M, Endo Y, Taira S, Sato Y, Fujita T, Ichikawa N, Nakta M, Mizuouchi T: A novel human serum lectin with collagenand fibrinogen-like domains that functions as an opsonin. J Biol Chem 1996;271:24482454.

11 Harumiya S, Omori A, Sugiura T, Fukumoto Y, Tachikawa H, Fujimoto D: EBP-37, a new elastin-binding protein in human plasma: structural similarity to ficolins, transforming growth factor-beta 1-binding proteins. J Biochem (Tokyo) 1995;117:1029-1035.

12 Endo Y, Sato Y, Matsushita M, Fujita T: Cloning and characterization of the human lectin P35 gene and its related gene. Genomics 1996;36:515-521.

-13 Edgar PF: Hucolin, a new corticosteroidbinding protein from human plasma with structural similarities to ficolins, transforming growth factor-beta 1- binding proteins. FEBS Lett 1995;375:159-161. 
-14 Fujimori Y, Harumiya S, Fukumoto Y, Miura Y, Yagasaki K, Tachikawa H, Fujimoto D: Molecular cloning and characterization of mouse ficolin-A. Biochem Biophys Res Commun 1998;244:796-800.

- 15 Lynch NJ, Khan SU, Stover CM, Sandrini SM, Marston D, Presanis JS, Schwaeble WJ: Composition of the lectin pathway of complement in Gallus gallus: absence of mannan-binding lectin-associated serine protease-1 in birds. J Immunol 2005; 174:49985006.

16 Omori-Satoh T, Yamakawa Y, Mebs D: The antihemorrhagic factor, erinacin, from the European hedgehog (Erinaceus europaeus), a metalloprotease inhibitor of large molecular size possessing ficolin/opsonin P35 lectin domains. Toxicon 2000;38:1561-1580.

-17 Kakinuma Y, Endo Y, Takahashi M, Nakata M, Matsushita M, Takenoshita S, Fujita T: Molecular cloning and characterization of novel ficolins from Xenopus laevis. Immunogenetics 2003;55:29-37.

-18 Kenjo A, Takahashi M, Matsushita M, Endo Y, Nakata M, Mizuochi T, Fujita T: Cloning and characterization of novel ficolins from the solitary ascidian, Halocynthia roretzi. J Biol Chem 2001;276:19959-19965.

$\checkmark 19$ Teh C, Le Y, Lee SH, Lu J: M-ficolin is expressed on monocytes and is a lectin binding to $\mathrm{N}$-acetyl-D-glucosamine and mediates monocyte adhesion and phagocytosis of Escherichia coli. Immunology 2000;101:225232.

-20 Hashimoto S, Suzuki T, Dong HY, Yamazaki $\mathrm{N}$, Matsushima K: Serial analysis of gene expression in human monocytes and macrophages. Blood 1999;94:837-844.

-21 Hashimoto S, Suzuki T, Dong HY, Nagai S, Yamazaki N, Matsushima K: Serial analysis of gene expression in human monocyte-derived dendritic cells. Blood 1999;94:845852.

22 Honore C, Rorvig S, Munthe-Fog L, Hummelshoj T, Madsen HO, Borregaard N, Garred P: The innate pattern recognition molecule ficolin-1 is secreted by monocytes/ macrophages and is circulating in human plasma. Mol Immunol 2008;45:2782-2789.

-23 Frankenberger M, Schwaeble W, ZieglerHeitbrock L: Expression of M-ficolin in human monocytes and macrophages. Mol Immunol 2007;45:1424-1430.

24 Muruve DA, Petrilli V, Zaiss AK, White LR, Clark SA, Ross PJ, Parks RJ, Tschopp J: The inflammasome recognizes cytosolic microbial and host DNA and triggers an innate immune response. Nature 2008;452:103-107.

25 Frederiksen PD, Thiel S, Larsen CB, Jensenius JC: $\mathrm{M}$-ficolin, an innate immune defence molecule, binds patterns of acetyl groups and activates complement. Scand J Immunol 2005;62:462-473.
Hummelshoj T, Munthe-Fog L, Madsen HO, Sim RB, Garred P: Comparative study of the human ficolins reveals unique features of ficolin-3 (Hakata antigen). Mol Immunol 2008;45:1623-1632.

27 Gulla KC, Gupta K, Gupta RK, Vyas V, Hajela K: Development of a fluorescence assay for the detection of L-ficolin-MASP in serum or purified samples. J Biochem Biophys Methods 2006;66:59-71.

28 Hummelshoj T, Munthe-Fog L, Madsen HO, Fujita T, Matsushita M, Garred P: Polymorphisms in the FCN2 gene determine serum variation and function of ficolin-2. Hum Mol Genet 2005;14:1651-1658.

29 Kilpatrick DC, Fujita T, Matsushita M: P35, an opsonic lectin of the ficolin family, in human blood from neonates, normal adults, and recurrent miscarriage patients. Immunol Lett 1999;67:109-112.

30 Krarup A, Sorensen UB, Matsushita M, Jensenius JC, Thiel S: Effect of capsulation of opportunistic pathogenic bacteria on binding of the pattern recognition molecules mannan-binding lectin, L-ficolin, and $\mathrm{H}$-ficolin. Infect Immun 2005;73:1052-1060.

-31 Munthe-Fog L, Hummelshoj T, Hansen BE, Koch C, Madsen HO, Skjodt K, Garred P: The impact of FCN2 polymorphisms and haplotypes on the Ficolin-2 serum levels. Scand J Immunol 2007;65:383-392.

32 Tenner AJ: Membrane receptors for soluble defense collagens. Curr Opin Immunol 1999; 11:34-41.

-33 Inaba S, Okochi K, Yae Y, Niklasson F, de Verder CH: Serological studies of an SLE-associated antigen-antibody system discovered as a precipitation reaction in agarose gel: the HAKATA antigen-antibody system. Fukuoka Igaku Zasshi 1990;81:284-291.

34 Epstein WV, Tan M: An antibody-like material in systemic lupus erythematosus directed toward a thermolabile serum macroprotein. Arthritis Rheum 1973;16:43-51.

35 Akaiwa M, Yae Y, Sugimoto R, Suzuki SO, Iwaki T, Izuhara K, Hamasaki N: Hakata antigen, a new member of the ficolin/opsonin p35 family, is a novel human lectin secreted into bronchus/alveolus and bile. J Histochem Cytochem 1999;47:777-785.

36 Ohashi T, Erickson HP: The disulfide bonding pattern in ficolin multimers. J Biol Chem 2004:279:6534-6539.

37 Matsushita M, Endo Y, Hamasaki N, Fujita T: Activation of the lectin complement pathway by ficolins. Int Immunopharmacol 2001; 1:359-363.

38 Krarup A, Thiel S, Hansen A, Fujita T, Jensenius JC: L-ficolin is a pattern recognition molecule specific for acetyl groups. J Biol Chem 2004;279:47513-47519.

39 Lu J, Le Y: Ficolins and the fibrinogen-like domain. Immunobiology 1998;199:190199.

40 Matsushita M, Fujita T: Ficolins and the lectin complement pathway. Immunol Rev 2001;180:78-85.
41 Erickson HP: Evolution of the tenascin family: implications for function of the C-terminal fibrinogen-like domain. Perspect Dev Neurobiol 1994;2:9-19.

42 Kobayashi R, Mizutani A, Hidaka H: Isolation and characterization of a $36-\mathrm{kDa}$ microfibril-associated glycoprotein by the newly synthesized isoquinolinesulfonamide affinity chromatography. Biochem Biophys Res Commun 1994;198:1262-1266.

43 Gokudan S, Muta T, Tsuda R, Koori K, Kawahara T, Seki N, Mizunoe Y, Wai SN, Iwanaga S, Kawabata S: Horseshoe crab acetyl grouprecognizing lectins involved in innate immunity are structurally related to fibrinogen. Proc Natl Acad Sci USA 1999;96: 10086-10091.

44 Garlatti V, Belloy N, Martin L, Lacroix M, Matsushita M, Endo Y, Fujita T, FontecillaCamps JC, Arlaud GJ, Thielens NM, Gaboriaud C: Structural insights into the innate immune recognition specificities of $\mathrm{L}$ - and H-ficolins. EMBO J 2007;26:623-633.

45 Tanio M, Kondo S, Sugio S, Kohno T: Trivalent recognition unit of innate immunity system: crystal structure of trimeric human M-ficolin fibrinogen-like domain. J Biol Chem 2007;282:3889-3895.

46 Thompson JD, Higgins DG, Gibson TJ: Clustal W: improving the sensitivity of progressive multiple sequence alignment through sequence weighting, position-specific gap penalties and weight matrix choice. Nucleic Acids Res 1994;22:4673-4680.

-47 Endo Y, Liu Y, Kanno K, Takahashi M, Matsushita M, Fujita T: Identification of the mouse $\mathrm{H}$-ficolin gene as a pseudogene and orthology between mouse ficolins $\mathrm{A} / \mathrm{B}$ and human L-/M-ficolins. Genomics 2004;84: 737-744.

48 Lu J, Tay PN, Kon OL, Reid KB: Human ficolin: cDNA cloning, demonstration of peripheral blood leucocytes as the major site of synthesis and assignment of the gene to chromosome 9. Biochem J 1996;313:473478 .

49 Rorvig S, Honore C, Larsson L-I, Ohlsson S, Pedersen CC, Jacobsen LC, Cowland JB, Garred P, Borregaard N: Ficolin-1 is present in a highly mobilizable subset of human neutrophil granules and associates with the cell surface after stimulation with fMLP. J Leukoc Biol 2009, DOI:10.1189/jlb.1008606.

50 Wittenborn T, Thiel S, Jensen L, Nielsen HJ, Jensenius JC: Characteristics and biological variations of $\mathrm{M}$-ficolin, a pattern recognition molecule, in plasma. J Innate Immun 2009; DOI: $10.1159 / 000218324$.

51 Tsujimura M, Miyazaki T, Kojima E, Sagara Y, Shiraki H, Okochi K, Maeda Y: Serum concentration of Hakata antigen, a member of the ficolins, is linked with inhibition of Aerococcus viridans growth. Clin Chim Acta 2002;325:139-146. 
-52 Munthe-Fog L, Hummelshoj T, Ma YJ, Hansen BE, Koch C, Madsen HO, Skjodt K, Garred P: Characterization of a polymorphism in the coding sequence of FCN3 resulting in a ficolin-3 (Hakata antigen) deficiency state. Mol Immunol 2008;45:26602666.

-53 Kuraya M, Matsushita M, Endo Y, Thiel S, Fujita T: Expression of $\mathrm{H}$-ficolin/Hakata antigen, mannose-binding lectin-associated serine protease (MASP)-1 and MASP-3 by human glioma cell line T98G. Int Immunol 2003; 15:109-117.

-54 Garred P: Mannose-binding lectin genetics: from A to Z. Biochem Soc Trans 2008;36: 1461-1466.

55 Worthley DL, Bardy PG, Mullighan CG: Mannose-binding lectin: biology and clinical implications. Intern Med J 2005;35:548555.

-56 Hellemann D, Larsson A, Madsen HO, Bonde J, Jarlo JO, Wiis J, Faber T, Wetterslev J, Garred P: Heterozygosity of mannosebinding lectin (MBL2) genotypes predicts advantage (heterosis) in relation to fatal outcome in intensive care patients. Hum Mol Genet 2007;16:3071-3080.

-57 Troelsen L, Garred P, Madsen HO, Jacobsen S: Genetically determined high serum levels of mannose-binding lectin and agalactosyl IgG are associated with ischemic heart disease in rheumatoid arthritis. Arthritis Rheum 2006;56:21-29.

58 Hansen TK, Gall MA, Tarnow L, Thiel S, Stehouwer CD, Schalkwijk CG, Parving HH, Flyvbjerg A: Mannose-binding lectin and mortality in type 2 diabetes. Arch Intern Med 2006;166:2007-2013.

-59 Herpers BL, Immink MM, de Jong BA, Velzen-Blad $\mathrm{H}$, de Jongh BM, van Hannen EJ: Coding and non-coding polymorphisms in the lectin pathway activator L-ficolin gene in 188 Dutch blood bank donors. Mol Immunol 2006;43:851-855.
60 Hummelshoj T, Munthe-Fog L, Madsen HO, Garred P: Functional SNPs in the human ficolin $(F C N)$ genes reveal distinct geographical patterns. Mol Immunol 2008;45:25082520.

61 Vander CB, Nuytinck L, Boullart L, Elewaut D, Waegeman W, Van TM, De ME, Lebeer K, Rossau R, De KF: Polymorphisms in the ficolin 1 gene (FCN1) are associated with susceptibility to the development of rheumatoid arthritis. Rheumatology (Oxford) 2007;46: 1792-1795.

62 Schlapbach LJ, Kessler U, Thiel S, Hansen AG, Nelle M, Ammann RA, Aebi C, Jensenius JC: $\mathrm{M}$-ficolin in the neonatal period: Associations with need for mechanical ventilation and mortality in premature infants with necrotising enterocolitis. Mol Immunol 2009;46:2597-2603.

63 Cedzynski M, Nuytinck L, Atkinson AP, St Swierzko A, Zeman K, Szemraj J, Szala A, Turner ML, Kilpatrick DC: Extremes of Lficolin concentration in children with recurrent infections are associated with single nucleotide polymorphisms in the FCN2 gene. Clin Exp Immunol 2007;150:99-104.

64 Chen X, Katoh Y, Nakamura K, Oyama N, Kaneko F, Endo Y, Fujita T, Nishida T, Mizuki N: Single nucleotide polymorphisms of ficolin 2 gene in Behcet's disease. J Dermatol Sci 2006;43:201-205.

65 Chapman SJ, Vannberg FO, Khor CC, Segal S, Moore CE, Knox K, Day NP, Davies RJ, Crook DW, Hill AV: Functional polymorphisms in the FCN2 gene are not associated with invasive pneumococcal disease. Mol Immunol 2007;44:3267-3270.
66 de Messias-Reason I, Kremsner PG, Kun JF: Functional haplotypes that produce normal ficolin-2 levels protect against clinical leprosy. J Infect Dis 2009;199:801-804.

67 Ma YJ, Doni A, Hummelshoj T, Honore C, Bastone A, Mantovani A, Thielens NM, Garred P: Synergy between ficolin-2 and PTX3 boost innate immune recognition and complement deposition. J Biol Chem 2009; DOI: $10.1074 / \mathrm{jbc} . M 109.009225$.

68 Ruskamp JM, Hoekstra MO, Postma DS, Kerkhof M, Bottema RW, Koppelman GH, Rovers MM, Wijga AH, de Jongste JC, Brunekreef B, Sanders EA: Exploring the role of polymorphisms in ficolin genes in respiratory tract infections in children. Clin Exp Immunol 2009; 155:433-440.

-69 de Messias-Reason I, Schafranski MD, Kremsner PG, Kun JFJ: Ficolin-2 (FCN2) functional polymorphisms and the risk of rheumatic fever and rheumatic heart disease. Clin Exp Immunol 2009;157:395-399.

70 Munthe-Fog L, Hummelshoj T, Honore C, Madsen HO, Permin H, Garred P: Immunodeficiency associated with FCN3 mutation and ficolin-3 deficiency. N Engl J Med 2009; 360:2637-2644.

71 Honore C, Hummelshoj T, Hansen BE, Madsen HO, Eggleton P, Garred P: The innate immune component ficolin 3 (Hakata antigen) mediates the clearance of late apoptotic cells. Arthritis Rheum 2007;56:1598-1607.

72 Wang CC, Yim KW, Poon TC, Choy KW, Chu CY, Lui WT, Lau TK, Rogers MS, Leung $\mathrm{TN}$ : Innate immune response by ficolin binding in apoptotic placenta is associated with the clinical syndrome of preeclampsia. Clin Chem 2007;53:42-52.

73 Schlapbach LJ, Aebi C, Hansen AG, Hirt A, Jensenius JC, Ammann RA: $\mathrm{H}$-ficolin serum concentration and susceptibility to fever and neutropenia in paediatric cancer patients. Clin Exp Immunol 2009;157:83-89. 